Reprod. Nutr. Dévelop., 1985, 25 (1 B), 217-226.

\title{
Lipid transport systems : some recent aspects in swine, cattle and trout during development
}

\author{
M. John CHAPMAN, Patricia FORGEZ
}

Equipe de recherches sur les lipoprotéines, INSERM Unité 9 Annexe, Pavillon Benjamin Delessert, Hôpital de la Pitié,

83, boulevard de l'Hôpital, 75671 Paris Cedex 13.

Summary. Lipids such as triacylglycerols, free and esterified cholesterol and phospholipids are essentially insoluble in water; lipoproteins, which are complex macromolecules of pseudomicellar structure, have evolved to ensure their efficient transport in the vascular system of vertebrates. Plasma lipoproteins are operationally classified according to their relative lipid and protein contents and thus according to density. The protein components, i.e. apolipoproteins, have a highly specialized structure contributing to particle stability and metabolism. The chemistry and structure of plasma lipoproteins and apoproteins is discussed and their biosynthesis, intravascular metabolism and cellular degradation briefly considered. Circulating concentrations of lipoproteins are under complex control, involving hormonal, nutritional and genetic factors ; changes occurring in lipoprotein levels in pigs (Sus domesticus), cattle (Bos sp.) and rainbow trout (Salmo gairdnerii) during development are discussed. In pigs and calves, LDL predominate at the fetal stage and VLDL are absent. During suckling, this pattern is rapidly modified with HDL becoming the major class and low levels of VLDL appearing. These changes in part reflect high levels of exogenous triglyceride lipolysis consequent to the ingestion of fat-rich, maternal milk. With further growth, HDL predominate in both adult pigs and steers, although the LDL : HDL ratio is considerably lower in the latter $(0.5-0.8$ and $\sim 0.2$, respectively). Our studies in pigs suggest that the intestinal secretion of lipoproteins commences rapidly after birth since proteins akin to human apo-B48 and apo-B100 are detectable in plasma VLDL some 2-3 h after parturition. Although the trout is an oviparous vertebrate, LDL is also preponderate at the juvenile stage. With sexual maturity, LDL and VLDL levels diminish progressively, plasma HDL attaining concentrations as high as $1,500 \mathrm{mg} / \mathrm{dl}$ in adults. Our knowledge of the biochemical mechanisms at the origin of these developmental changes in lipid transport in both mammals and fish remains largely incomplete.

\section{Introduction.}

Lipoproteins which circulate in the vascular system of vertebrates are macromolecular complexes of lipids and of certain specialized proteins, the apolipoproteins. The physical structure and organization of these complexes, which were first isolated by Machebœuf (1929), have been compared to that of a pseudomicelle with the polar components, i.e. phospholipids and apolipoproteins, 
situated at the surface and the more hydrophobic constituents, i.e. triglycerides, cholesteryl esters and some free cholesterol, located in the core of the particle. These particles transport water-soluble lipids, namely triglycerides, cholesteryl esters, free cholesterol and phospholipids, from sites of lipid absorption (gastrointestinal tract) and biosynthesis (typically liver and gut) to sites of storage and utilization. Lipid transport and metabolism differ markedly between the higher (mammals) and the lower (birds, amphibians, reptiles and fishes) vertebrates (Chapman, 1980), as might be expected from the contrasting anatomies and diets of these two groups.

The principal structural and metabolic characteristics of the major classes of plasma lipoproteins in mammalian species, and notably in man, are briefly summarized below. We shall then consider modifications occurring in lipid transport during development in two mammals of agronomic interest and importance, i.e. the cow (Bos sp.) and the pig (Sus domesticus). Available data on changes in the lipid transport system in an oviparous vertebrate, the rainbow trout (Salmo gairdnerii), will be discussed as a function of age and sexual maturation.

\section{Classification and chemical composition of serum lipoproteins.}

Lipoproteins of human serum can be divided into five major classes (table 1) : chylomicrons (particles of lowest density and largest size), very-low-density lipoproteins (VLDL), low-density lipoproteins (LDL), high-density lipoproteins (HDL) and very-high-density lipoproteins (VHDL). These five groups are often classified according to density (table 1); as lipoprotein particle density increases, the lipid content of the particle diminishes and the protein content increases. Thus, while chylomicrons consist of $98 \%$ or more of lipid and have a $d<0.94 \mathrm{~g} / \mathrm{ml}$, the VHDL consist almost exclusively of protein $(65-99 \%)$ and have a $\mathrm{d}>1.21 \mathrm{~g} / \mathrm{ml}$. The result is a spectrum of particles varying widely in molecular weight, hydrated density, net electrical charge (as judged by electrophoretic mobility) and size (table 1).

TABLE 1

Physicochemical properties of the major classes of human serum lipoproteins.

\begin{tabular}{lccccrr}
\hline $\begin{array}{c}\text { Lipoprotein } \\
\text { class }\end{array}$ & $\begin{array}{c}\text { Density } \\
(\mathrm{g} / \mathrm{ml})\left(^{*}\right)\end{array}$ & Molecular weight & $\begin{array}{c}\text { Diameter } \\
(\AA)\end{array}$ & $\begin{array}{c}\text { Electrophoretic } \\
\text { mobility }\end{array}$ & $\begin{array}{c}\text { Lipid } \\
(\%)\end{array}$ & $\begin{array}{c}\text { Protein } \\
(\%)\end{array}$ \\
\hline Chylomicrons. & $<0.94$ & $5 \times 10^{8}-4.3 \times 10^{11}$ & $750-10000$ & Origin & 98 & 2 \\
VLDL $\ldots \ldots \ldots$ & $0.94-1.006$ & $3 \times 10^{6}-1.3 \times 10^{8}$ & $300-800$ & Pre- $\beta\left(\alpha_{2}\right)$ & 92 & 8 \\
LDL $\ldots \ldots \ldots$ & $1.006-1.063$ & $2.5 \times 10^{3}$ & $200-300$ & $\beta$ & 75 & 25 \\
$\mathrm{HDL}_{2}\left(^{* *}\right) \ldots$ & $1.063-1.125$ & $2 \times 10^{3}$ & $85-100$ & $\alpha_{1}$ & 60 & 40 \\
$\mathrm{HDL}_{3}\left(^{* *}\right) \ldots$ & $1.125-1.21$ & $1.6 \times 10^{3}$ & $70-85$ & $\alpha_{1}$ & 45 & 55 \\
VHDL $\ldots \ldots$ & $>1.21$ & $25-150 \times 10^{3}$ & - & $\alpha_{1}$ & $35-1$ & $65-99$ \\
\hline
\end{tabular}

${ }^{*}$ ) These values correspond to the density intervals originally employed for the isolation of each class and are distinct from their hydrated densities.

$\left.{ }^{* *}\right)$ The HDL class is divided into its two principle subclasses, $\mathrm{HDL}_{2}$ and $\mathrm{HDL}_{3}$. 
It is noteworthy that particles with the highest lipid content, i.e. chylomicrons and VLDL, have the highest molecular weight and largest molecular diameter, thereby reflecting a voluminous lipid core.

The most abundant components of VHDL are serum proteins such as albumin; the role of these proteins is to transport free fatty acids from the adipose tissue to sites of utilization, such as muscles and liver, and to vehicule metabolic products derived from other lipoproteins, such as lysolecithin, resulting from the action of lecithin: cholesterol acyl transferase (LCAT) on HDL phospholipid. VHDL are thus complexes either of free fatty acids and albumin or of lysolecithin and other phospholipids and albumin. Other proteins, particularly apolipoprotein $\mathrm{Al}$, are found in VHDL.

The chemical composition of the major classes of serum lipoproteins as they occur in man are shown on table 2.

The triglyceride-rich lipoproteins are chylomicrons and VLDL. In humans, LDL represent the major form in which cholesterol is transported, primarily as its ester. In contrast, $\mathrm{HDL}_{2}$ and $\mathrm{HDL}_{3}$ contain less cholesterol and an elevated proportion of phospholipid (20-30\% by weight). It is therefore already evident that the lipoproteins mainly implicated in triglyceride transport are chylomicrons and VLDL, whereas LDL and HDL are responsible for the bulk of cholesterol transport.

TABLE 2

Chemical composition of human serum lipoproteins.

\begin{tabular}{|c|c|c|c|c|c|}
\hline \multirow{2}{*}{ Component } & \multicolumn{5}{|c|}{ Lipoprotein class $\left({ }^{*}\right)$} \\
\hline & Chylomicrons & VLDL & $\begin{array}{c}\mathrm{LDL} \\
\text { (\% by weight) }\end{array}$ & $\mathrm{HDL}_{2}$ & $\mathrm{HDL}_{3}$ \\
\hline $\begin{array}{l}\text { Cholesteryl ester } \\
\text { Free cholesterol } \\
\text { Triglyceride } \ldots \ldots \\
\text { Phospholipid } \ldots \ldots \\
\text { Protein } \ldots \ldots \ldots\end{array}$ & $\begin{array}{r}5 \\
2 \\
84 \\
7 \\
2\end{array}$ & $\begin{array}{r}12 \\
7 \\
53 \\
18 \\
10\end{array}$ & $\begin{array}{r}37 \\
8 \\
10 \\
22 \\
23\end{array}$ & $\begin{array}{r}17 \\
5 \\
5 \\
31 \\
42\end{array}$ & $\begin{array}{r}12 \\
4 \\
4 \\
24 \\
56\end{array}$ \\
\hline
\end{tabular}

(*) The density intervals are those given in Table 1.

\section{Apolipoproteins.}

As already mentioned, the lipoprotein particles of vertebrate plasma possess variable amounts of specialized lipid-binding proteins, i.e. apoproteins or apolipoproteins. Indeed, the various classes of lipoproteins are differentiated as well by their protein moities as by other commonly-used parameters such as density, net charge, electrophoretic mobility and molecular size. Alaupovic (1980) originally proposed to classify lipoproteins according to their apolipoprotein constituents. The most recent procedures for lipoprotein fractionation using immunoabsorbent affinity chromatography, which is highly resolutive and has a minimal effect on lipoprotein structure, depend on the specific structural characteristics of apoproteins as a means of isolating highly purified and precisely defined particles. 
The apolipoproteins present in chylomicrons, VLDL, LDL and HDL of human serum are indicated on table 3 ; their analogues, especially those of the $A, B, C$ and $E$ groups, occur widely in mammals (Chapman, 1980).

Apoproteins $A$ are primarily found in $\mathrm{HDL}$, and apo-B in LDL. The $B, C$ and $E$ groups form the major portion of the protein moiety of VLDL, and $A, B$ and $C$ that of chylomicrons. Almost all of the low molecular weight apolipoproteins (excluding the $B$ proteins whose apparent $M_{r}$ values are all $>100,000$ daltons) are polymorphic; this may be due to several factors. One is the degree of sialylation of the carbohydrate side-chain, as in apo-C III, and another may be amino acid substitution (e.g. arginine/cysteine) at certain sites, as in apo-E and possibly in apo-Al; a third factor may be the presence of small amounts of proapolipoprotein, as in the case of (prolapo-Al. Apo-B is also polymorphic, there being a circulating form which is synthesized in the intestine (B48 in man) and another (B100) which is hepatic in origin.

The average circulating levels of the major lipoproteins and apoproteins found in normolipidemic males 25 to 40 years old are given.on table 4 . LDL and

TABLE 3

Apolipoprotein composition of human plasma lipoproteins.

\begin{tabular}{lllll}
\hline & Chylomicrons & VLDL & LDL & HDL \\
\hline \multirow{4}{*}{ Major apoproteins } & Apo-Al & Apo-B & Apo-B & Apo-Al \\
& Apo-B & Apo-Cl & & Apo-All \\
& Apo-C (*) & Apo-Cll & & \\
& & Apo-CIII & & \\
& & Apo-E & & \\
& Apo-All & Apo-Al & Apo-C & Apo-CI \\
& Apo-E & Apo-All & Apo-E & Apo-CII \\
Minor apoproteins & PRP (**) & Apo-D & & Apo-CIII \\
$1<10 \%$ of totai) & Apo-AIV & & & Apo-D \\
& & & & Apo-E \\
& & & & Apo-F \\
& & & Apo-AlV \\
\hline
\end{tabular}

$\left.{ }^{*}\right)$ All the apolipoprotein characteristic of this group are present.

(**) Proline-rich peptide.

TABLE 4

Plasma concentrations of lipoproteins and apolipoproteins in man.

\begin{tabular}{|c|c|c|c|}
\hline \multicolumn{2}{|c|}{ Lipoproteins } & \multicolumn{2}{|c|}{ Apolipoproteins } \\
\hline & $\mathrm{mg} / 100 \mathrm{ml}$ & & $\mathrm{mg} / 100 \mathrm{ml}$ \\
\hline $\begin{array}{l}\text { VLDL } \ldots \ldots \ldots \ldots \ldots \ldots \\
\mathrm{LDL} \ldots \ldots \ldots \ldots \ldots \ldots \\
\mathrm{HDL}_{2} \ldots \ldots \ldots \ldots \ldots \ldots \ldots \\
\mathrm{HDL}_{3} \mathrm{HDL}_{2} / \mathrm{HDL}_{3} \ldots \ldots \ldots \ldots \ldots\end{array}$ & $\begin{array}{r}80 \\
276 \\
86 \\
254 \\
0,36\end{array}$ & $\begin{array}{l}\text { Apo-B } \\
\text { Apo-Al } \\
\text { Apo-All } \\
\text { Apo-E } \\
\text { Apo-Cl } \\
\text { Apo-CII } \\
\text { Apo-CIII } \\
\text { Apo-D } \\
\text { Apo-AIV }\end{array}$ & $\begin{array}{c}80-100 \\
120-150 \\
20-80 \\
\sim 10 \\
5-10 \\
3-5 \\
15-20 \\
10-20 \\
15\end{array}$ \\
\hline
\end{tabular}


$\mathrm{HDL}_{3}$ are typically present at highest concentrations as are their major apolipoproteins, apo-B (100) and apo-Al.

This discussion of the physicochemical properties of plasma lipoproteins and apolipoproteins is not intended to be exhaustive; for further information on their chemistry and structure, the reader is referred to some reviews which have appeared in recent years (Osborne and Brewer, 1977; Kane, 1977; Smith, Pownall and Gotto, 1978 ; Alaupovic, 1980 ; Kane, 1983).

In the preceding discussion, one or two major points relevant to lipoprotein chemistry should be emphasized. Firstly, the composition of the lipoproteins described is not constant but is subject to continuous dynamic charge in the circulation. Secondly, each density class of lipoprotein is highly heterogenous, not only in structure but also in metabolism. Thirdly, the profile of lipoprotein particles circulating at any given moment is the result of the interplay of a host of physiological processes, among which biosynthesis and secretion, intravascular modification and tissue catabolism are predominant.

\section{Formation and functions of lipoproteins and apoproteins.}

We have extensive data on the biochemical mechanism involved in the intestinal absorption of dietary lipids and the biosynthesis and secretion of nascent chylomicrons, VLDL and HDL in the intestine and liver; we also have accumulated knowledge concerning the origin and properties of remnant lipoproteins. The literature has been reviewed recently by Dietschy, Gotto and Ontko (1978). In the same volume, the transport and metabolism of fatty acids is also extensively discussed.

Finally, for an up-to-date treatment of the multiple facets of the intravascular metabolism and tissue degradation of lipoproteins by receptor and non-receptordependent pathways, the reader is referred to the reports of Brown, Kovanen and Goldstein (1981), Mahley and Innerarity (1983), Havel, Goldstein and Brown (1980), Havel (1982) and Chapman (1982).

\section{Developmental aspects of lipid transport.}

Cattle. - The lipoprotein and apolipoprotein profiles in species of adult cattle (notably Holstein, Guernsey and Jersey cows) have been thoroughly described by Puppione and colleagues (Puppione et al., 1982a ; 1982b ; Puppione, 1983) ; data available up to 1980 have been reviewed by Chapman (1980). These profiles vary considerably according to physiological and nutritional state and particularly in relation to gestation and lactation. Nonetheless, HDL and apo-Al are usually the major constituents of the plasma. The structure, distribution and metabolism of lipoproteins occurring in the low-density interval (nominally $1.006-1.063 \mathrm{~g} / \mathrm{ml}$ ) in bovine plasma are particularly complex and are still not fully understood any more than is the role of lipid-transfer proteins and lecithin : cholesterol acyl transferase in their intravascular transformation. In this respect, it is particularly necessary to examine the methodology employed for the fractionation of bovine plasma lipoproteins because of their extraordinary complexity (at least as 
concerns $L D L$ ) and also because of the elevated contents of saturated fatty acids in their lipid esters (Puppione et al., 1982a).

In contrast to adult plasma, LDL are the major particles in fetal calf plasma, although levels of both LDL and HDL are less than $50 \mathrm{mg} / 100 \mathrm{ml}$ of serum (Forte, Bell-Quint and Cheng, 1981). With the onset of suckling, however, dramatic changes occur in the newborn profile, HDL rapidly attaining levels of up to $200 \mathrm{mg} / 100 \mathrm{ml}$, while LDL concentrations decrease slightly. Such alterations reflect the change from nutrition via the umbilical cord to intestinal assimilation of maternal milk lipid, with consequent increases in circulating triglyceride levels and associated lipolysis; VLDL are absent from fetal calf serum but present at low levels in both newborn and adult animals $(10-20 \mathrm{mg} / 100 \mathrm{ml}$ of serum). Interestingly, the protein content of calf HDL decreased progressively with growth and development, a finding consistent with the lower density of HDL in adults (Forte, Bell-Quint and Cheng, 1981), while LDL and VLDL were enriched in cholesteryl esters and triglyceride, respectively, as in man. Apolipoprotein Al predominated in HDL at all developmental stages ; in LDL, apo-B was the sole apoprotein in fetal calves, whereas LDL from newborn and adult animals also contained apo-Al and $\mathrm{C}$ proteins. Such $\mathrm{C}$ apolipoproteins were lacking at the fetal stage, suggesting that feeding triggers intestinal synthesis and secretion.

Although little is known of the developmental changes occurring in the levels and activities of lipolytic enzymes, it is to be noted that discoid forms of HDL could not be seen by Forte, Bell-Quint and Cheng (1981) at the fetal stage ; this suggests that some LCAT activity existed before parturition. Finally, Lascelles and Wadsworth (1971), in an early study on the lipoproteins of the intestinal and hepatic lymph of unsuckled, newborn calves, found evidence for a significant role of biliary phospholipids in supplying fatty acids for the VLDL triglycerides of intestinal lymph. These authors concluded that most of the lipid in calf lymph VLDL was derived from bile. It is also reasonable to assume that the rate of lipolysis is high in newborn calves since, despite elevated levels of lymph VLDL, amounts of VLDL in the plasma remained low.

Pigs. - The developmental changes in pigs are similar to those described in cattle. In the most comprehensive study to date, Johansson and Karlsson (1982) have shown that the major lipoprotein in fetal pig serum, at least until day 90 of gestation, is an LDL-like particle, as judged by its electrophoretic mobility and by immunoassay using an antiserum to adult LDL. Thus, although these authors quote the values as a $\%$ of those in adults [adult values : $\sim 120 \mathrm{mg} / 100 \mathrm{ml}$ and $\sim 180 \mathrm{mg} / 100 \mathrm{ml}$ of serum for LDL and HDL, respectively ; Chapman (1980)], calculation showed LDL and HDL levels to be about 80 and $50 \mathrm{mg} / 100 \mathrm{ml}$, respectively, in early fetal life ( $\sim 70$ days). Subsequently and at the end of the fetal period, HDL predominated slightly $(\sim 70$ and $60 \mathrm{mg} / 100 \mathrm{ml}$ in $\mathrm{HDL}$ and LDL, respectively) in Johansson and Karlsson's study. These values contrast with those obtained in preliminary studies in our laboratory, in which ultracentrifugally isolated LDL was preponderate at parturition (table 5). This profile altered considerably after birth, the LDL levels rapidly attaining those typical of the adult within 5 days of parturition; within a similar period, the HDL rose to levels twice 
TABLE 5

Porcine lipoprotein levels during development $\left({ }^{1}\right)$.

\begin{tabular}{|c|c|c|c|}
\hline \multirow[b]{2}{*}{ Stage } & \multicolumn{3}{|c|}{ Plasma concentration $(\mathrm{mg} / \mathrm{dl})$} \\
\hline & VLDL & $\operatorname{IDL}+\operatorname{LDL}\left({ }^{2}\right)$ & HDL \\
\hline 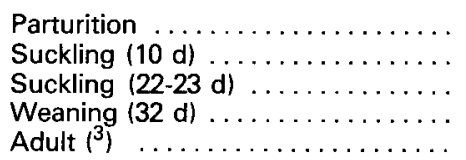 & $\begin{array}{l}27 \\
24 \\
41 \\
60 \\
40\end{array}$ & $\begin{array}{c}130 \\
180 \\
170 \\
120 \\
125-200\end{array}$ & $\begin{array}{c}100 \\
230 \\
270 \\
170 \\
100-180\end{array}$ \\
\hline
\end{tabular}

(1) Lipoproteins were fractionated from piglet plasma by density gradient ultracentrifugation (Chapman et al., 1981) and quantitated by chemical analysis (Chapman et al., 1981).

(2) The content of IDL in this fraction did not exceed $10 \%$ of the total.

(3) Values in adult pigs are taken from data discussed in the review of Chapman (1980).

those of mature pigs (Johansson and Karlsson, 1982). These findings are largely consistent with ours (table 5 ) during the suckling period (up to $\sim 22 / 23$ days). After weaning, both LDL and HDL concentrations diminished to those typical of adults (table 5 ; Johansson and Karlsson, 1982), although the latter authors found that HDL remained twofold higher even up to 8 weeks after birth. The reason for the discrepancy between their data and ours is not evident at this time. VLDL levels tended to increase with age during suckling, attaining a maximum $(\sim 60 \mathrm{mg} / 100 \mathrm{ml})$ some 10 days after weaning (table 5); at no time were they significantly higher than those characterizing mature pigs. In view of the high fat intake from maternal milk, the stability of circulating VLDL levels during the suckling period suggests that the lipolytic system for degrading exogenouslyderived triglycerides in piglets is highly efficient; this proposal agrees with Mersmann (1974) who reported that the capacity to produce endogenous fatty acids for energy generation is limited in newborn piglets.

Since 1980, it has been established by Kane (1983) that a specific form of apolipoprotein B, termed B48 and found in chylomicrons and VLDL, is a product of intestinal biosynthesis and secretion in man. We were therefore very interested in determining at which developmental stage this protein appeared in porcine lipoproteins. After VLDL and LDL of piglet plasma had been fractionated by density gradient ultracentrifugation (Chapman et al., 1981), their apoproteins were analysed by electrophoresis in SDS-polyacrylamide gel (fig. 1). The gel patterns revealed that a protein with an apparent molecular weight $(240,000-280,000)$ resembling that of human $B 48(\sim 260,000)$ (Kane, 1983) was present in plasma VLDL as early as $2-3 \mathrm{~h}$ after parturition and persisted throughout suckling. In addition, a protein akin to human $B 100$ and of $M_{r} 500,000-540,000$ was present in both VLDL and LDL at all developmental stages (fig. 1). Clearly then, intestinal apolipoprotein synthesis and secretion commence in pigs at least as early as 2-3 $\mathrm{h}$ after parturition when suckling has already begun.

Rainbow trout. - The serum lipoprotein profile in adult rainbow trout is dominated by HDL which may attain levels as high as $1,500-2,000 \mathrm{mg} / 100 \mathrm{ml}$ of serum (Chapman, 1980). In contrast, LDL concentrations range from 100 to 
VLDL

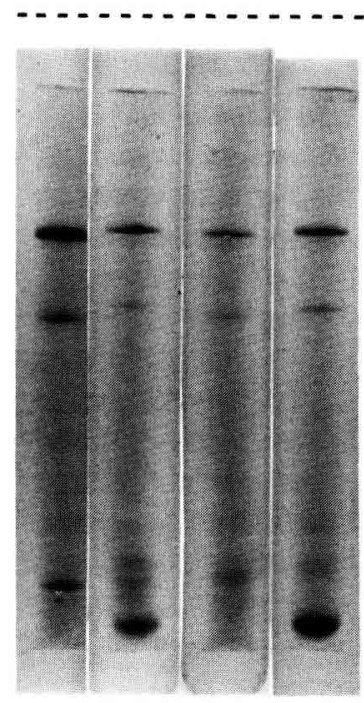

p 102232

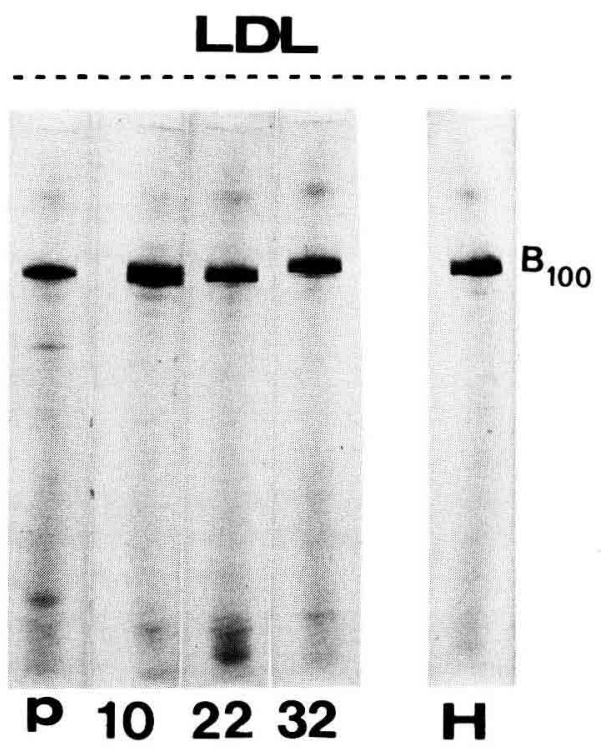

FIG. 1. - Electrophoresis in SDS-polyacrylamide gel of apo-VLDL and apo- $L D L$ from piglets at different developmental stages. VLDL and LDL were isolated by density gradient ultracentrifugation (Chapman et al., 1981) from piglet plasma taken at parturition ( $P$ ) and at 10, 22 and 32 neonatal days. These patterns are compared to those of human VLDL $(H)$ and human LDL (H) isolated by the same procedure. The acrylamide monomer concentration was $3 \% ; 40 \mu \mathrm{g}$ of protein was applied to each gel. After electrophoresis, the gels were stained with Coomassie Blue R250. Other aspects of this gel methodology have been described elsewhere by Forgez, Chapman and Mills (1983).

$400 \mathrm{mg} / \mathrm{dl}$, with VLDL being even more variable $(\sim 10-200 \mathrm{mg} / \mathrm{dl})$. Such variations may be at least partly explained by differences in age, sex and physiological and nutritional state.

Despite the paucity of information on lipid transport in relation to development in trout, it nonetheless appears that age, sex and stage of sexual maturity and activity are the major factors influencing circulating lipoprotein levels (Frémont and Marion, 1982 ; Perrier et al., 1979). In juvenile, sexually immature male trout, LDL were predominant, being present at concentrations as high as $100 \mathrm{mg} / \mathrm{dl}$ or more (Frémont and Marion, 1982) ; at this stage (1 year old), VLDL and HDL levels were similar (approx. $330 \mathrm{mg} / \mathrm{dl}$ of serum). With sexual maturation, the amounts of VLDL and LDL decreased progressively up to the second sexual cycle, at which point HDL levels were some twentyfold and twofold higher, respectively, at around $1,000 \mathrm{mg} / \mathrm{dl}$. The precise mechanisms underlying these alterations remain to be established, but both LCAT and lipoprotein lipase activities would be expected to participate. Indeed, Skinner and Youssef (1982) have recently characterized lipoprotein lipase from post-heparin trout plasma. It is most probable that the circulating lipoproteins in trout 
contribute to gametogenesis and gonadal development since they may supply cholesterol and lipids not only for steroidogenesis but also for membrane formation. To more completely understand the role of lipoproteins in these processes, they must be studied in parallel with circulating hormone levels throughout the sexual cycle. Finally, we should not overlook the role of lipoproteins in providing polyunsaturated fatty acids to various developing tissues for the maintenance of membrane lipid fluidity at low temperature, a requirement which is presumably elevated during sexual maturation itself as well as at certain stages of the subsequent sexual cycles.

10 e Réunion du groupe Développement I.N.R.A., Rennes, 9-10 mai 1984.

Acknowledgements. - We are most grateful to M. M. Etienne, I.N.R.A. St-Gilles, for the gift of piglet plasma. P. F. gratefully acknowledges the award of a Research Fellowship from ICl-Pharma.

Résumé. Les formes de transport des lipides : quelques aspects récents chez le porc, le bovin et la truite au cours du développement.

La chimie et la structure des lipoprotéines et apolipoprotéines plasmatiques sont présentées brièvement avant d'exposer leurs fonctions, leurs biosynthèses et leurs dégradations intravasculaire et tissulaire. A la suite, sont discutés les aspects du profil des lipoprotéines et apolipoprotéines au cours du développement chez le bovin, le porc et la truite.

\section{References}

ALAUPOVIC P., 1980. Structure and function of plasma lipoproteins with particular regard to hyperlipoproteinemias and atherosclerosis. Ann. biol. clin., 38, 83-93.

BROWN M. S., KOVANEN P. T., GOLDSTEIN J. L., 1981. Regulation of plasma cholesterol by lipoprotein receptors. Science, 212, 628-635.

CHAPMAN M. J., 1980. Animal lipoproteins : chemistry, structure and comparative aspects. $J$. Lipid Res., 21, 789-853.

CHAPMAN M. J., 1982. Les lipoprotéines et le foie. Gastroentérol. clin. biol., 6, 482-499.

CHAPMAN M. J., GOLDSTEIN S., LAGRANGE D., LAPLAUD P. M., 1981. A density gradient ultracentrifugal procedure for the isolation of the major lipoprotein classes from human serum. J. Lipid Res., 22, 339-358.

DIETSCHY J. M., GOTTO A. M., ONTKO J. A. (ed.), 1978. " Disturbances in lipid and lipoprotein metabolism. Am. physiol. Soc. Bethesda, Md.

FORGEZ P., CHAPMAN M. J., MILLS G. L., 1983. Isolation, characterisation and comparative aspects of the major serum apolipoproteins $\mathrm{B}-100$ and $\mathrm{Al}$, in the common marmoset, Callithrix jacchus. Biochim. biophys. Acta, 754, 321-333.

FORTE T. M., BELL-QUINT J. J., CHENG F., 1981. Lipoproteins of fetal and new-born calves and adult steer : a study of developmental changes. Lipids, 16, 240-245.

FRÉMONT L., MARION D., 1982. A comparison of the lipoprotein profiles in male trout (Salmo gairdneri) before maturity and during spermiation. Comp. Biochem. Physiol., 73B, 849-855.

HAVEL R. J. (ed.), 1982. Medical clinics of North America : lipid disorders. Vol. 66. W. B. Saunders, Philadelphia, PA. 
HAVEL R. J., GOLDSTEIN J. L., BROWN M. S., 1980. Lipoproteins and lipid transport, 393-494. In BONDY P. K., ROSENBERG L. B., Metabolic control and disease. W. B. Saunders CO., Philadelphia.

JOHANSSON M. B. N., KARLSSON B. W., 1982. Lipoprotein and lipid profiles in the blood serum of fetal, neonatal and adult pig. Biol. Neonate, 42, 127-137.

KANE J. P., 1977. Plasma lipoproteins : structure and metabolism, 209-258. In SNYDER F., Lipid metabolism in mammals, vol. I, Plenum Press, New York.

KANE J. P., 1983. Apolipoprotein B : structural and metabolic heterogeneity. Ann. Rev. Physiol., 45, 637-650.

LASCELLES A. K., WADSWORTH J. C., 1971. The origin of lipoprotein in the intestinal and hepatic lymph of unsuckled new-born calves. J. Physiol., 214, 443-455.

MACHEBOEUF M., 1929. Recherches sur les phosphoaminolipides et les stérides du sérum et du plasma sanguins. I. Entraînement des phospholipides, des stérols et des stérides par les diverses fractions au cours du fractionnement des protéides du sérum. Bull. Soc. Chim. biol., 11, 268-293.

MAHLEY R. W., INNERARITY T. L., 1983. Lipoprotein receptors and cholesterol homeostasis. Biochim. biophys. Acta, 737, 197-222.

MERSMANN H. J., 1974. Metabolic patterns in the neonatal swine. J. anim. Sci, 38, 1022-1030.

OSBORNE J. C., BREWER H. B., 1977. The plasma lipoproteins. Adv. Protein Chem., 31, 253-337.

PERRIER H., PERRIER C., PERES G., GRAS J., 1979. The lipoproteins of the plasma of the rainbow trout (Salmo gairdnerii Richardson) : immunoelectrophoresis, selective precipitation and lipid composition. Comp. Biochem. Physiol., 62B, 245-248.

PUPPIONE D. L., 1983. Bovine serum lipoproteins, 185-202. In LEWIS L. A., NAITO H. K., Handbook of electrophoresis, vol. IV. CRC Press, Boca Raton, Florida.

PUPPIONE D. L., KUNITAKE S. T., HAMILTON R. L., PHILIPS M. L., SCHUMAKER V. N., DAVIS L. D., 1982a. Characterisation of unusual intermediate density lipoproteins. J. Lipid Res., 23, 283-290.

PUPPIONE D. L., KUNITAKE S. T., TOOMEY M. L., LOH E., SCHUMAKER V. N., 1982b. Physicochemical characterisation of ten fractions of bovine alpha lipoproteins. J. Lipid Res., 23, 371379.

SKINNER E. R., YOUSSEF A. M., 1982. The characterisation of lipoprotein lipase isolated from the post-heparin plasma of the rainbow trout, Salmo gairdnerii Richardson. Biochem. J., 203, 727-734.

SMITH L. C., POWNALL H. J., GOTTO A. M., 1978. The plasma lipoproteins : structure and metabolism. Ann. Rev. Biochem., 47, 751-777. 